\title{
Coconut-Fibre Biofilm Wastewater Treatment System in Sri Lanka: Microcosm Experiments for Evaluating Wastewater Treatment Efficiencies and Oxygen Consumption
}

\author{
Naofumi Sato, Takeshi Saito, Hiroyasu Satoh, Norio Tanaka, and Ken Kawamoto
}

\begin{abstract}
This study evaluated the performance of a coconut-fibre biofilm wastewater treatment system (COTS) by utilizing microcosm experiments in the laboratory. In the microcosm experiments, two types of wastewater, synthetic sewage and leachate, with different pollutant loads were used. Three coconut-fibre conditions, a single bundle (low fibre density), two bundles (high fibre density), and no coconut fibre (blank) were set in the experiments. Water quality parameters (pH, DO, EC, BOD, COD, TC, TOC, TN and TP) of effluents were measured at one-week intervals, and removal \% of $\mathrm{BOD}$, COD, TC, TN and TP was evaluated. There was a clear increase in the oxygen consumption for the synthetic leachate with increasing the coconut fibre density. Besides, the removal \% of pollutants was highly dependent on the load conditions, implying that the proper control of pollutant loads is effective to enhance the treatment efficiencies in COTS.
\end{abstract}

Index Terms-Sewage, landfill leachate, coconut-fibre, biofilm treatment, microcosm experiment.

\section{INTRODUCTION}

Improper treatment of wastewater of collected sewage and leachate at waste dumping sites causes serious environmental degradation in developing countries. In order to solve these problems, it is important to introduce sustainable and low-cost wastewater treatment systems. In Sri Lanka, most of the collected sewage is directly discharged in vacant lands, forests, streams, or excavated pits without any treatment, although the amount of sewage collected has been increasing with the dissemination of separate toilets [1]. In addition, the open dumping of collected solid waste without any leachate treatment causes surface, groundwater pollution, and the numerous resident complaints [2], [3].

As natural biofilm support media for wastewater treatment, the interest in the utilization of locally available biomass resources for application is increasing because of its low cost and low technology. For instance, some local authorities in Sri Lanka have introduced a coconut-fibre biofilm treatment system (COTS) to treat the collected sewage and leachate at waste disposal sites [1]. The COTS treated well and water quality parameters such as $\mathrm{COD}, \mathrm{BOD}$, and $\mathrm{NH}_{4}{ }^{+}-\mathrm{N}$ decreased from inlet to outlet at all sites. However, the mechanisms of wastewater treatment in COTS and

Manuscript received June 12, 2017; revised September 24, 2017.

The authors are with Graduate School of Science and Engineering, Saitama University, Japan, EX Research Institute Ltd., Japan (e-mail: naofumi.sato@exri.co.jp, hiroyasu@k.u-tokyo.ac.jp, kawamoto@mail.saitama-u.ac.jp). quantitative analyses for designing and optimizing the system are not fully understood. In the context of these motivations, authors carried out microcosm experiments in the laboratory using both synthetic sewage and leachate to evaluate the wastewater treatment efficiencies of COTS [4]. Based on the results of laboratory tests, the microcosm COTS contributes to the reduction of water quality parameters, such as BOD and COD, especially of the synthetic leachate, and higher consumptions of $\mathrm{C}$ and $\mathrm{N}$ observed in the conditions of higher coconut-fibre density due to higher sludge sedimentation. This paper added further analysis to evaluate treatment efficiencies of microcosm COTS and discussed oxygen consumption in the system.

\section{Materials AND Methods}

\section{A. Materials}

Coconut (Cocos nucifera L.) fibre was used as microorganism adhesion and biofilm formation because of its rich in hard organic matter with high specific surface area and wetting ability. The preparation of synthetic sewage was adapted from data measured at Balangoda Urban Council in Sri Lanka [1] and reported data [5]. On the other hand, the preparation of synthetic sewage and leachate was adapted from reported data and previous studies with some modifications [6]-[8]. Measured water qualities of supplied synthetic sewage and synthetic leachate are shown in Table I.

\begin{tabular}{|c|c|c|c|c|c|}
\hline \multirow{2}{*}{\multicolumn{2}{|c|}{$\begin{array}{l}\text { Wastewater } \\
\text { Pollutant load }\end{array}$}} & \multicolumn{2}{|c|}{ Synthetic sewage } & \multicolumn{2}{|c|}{ Synthetic leachate } \\
\hline & & Low & High & Low & High \\
\hline $\mathrm{pH}$ & & 8.2 & 7.6 & 8.1 & 7.8 \\
\hline DO & $\mathrm{mg} / \mathrm{L}$ & 5.0 & 2.9 & 0.2 & 0.1 \\
\hline $\mathrm{EC}$ & $\mathrm{mS} / \mathrm{m}$ & 564 & 1,340 & 710 & 1,790 \\
\hline BOD & $\mathrm{mg} / \mathrm{L}$ & 1,450 & 5,930 & 938 & 14,300 \\
\hline COD & $\mathrm{mg} / \mathrm{L}$ & 1,770 & 6,360 & 1,720 & 21,400 \\
\hline $\mathrm{TC}$ & $\mathrm{mg} / \mathrm{L}$ & 955 & 3,420 & 705 & 6,490 \\
\hline TOC & $\mathrm{mg} / \mathrm{L}$ & 529 & 3,020 & 406 & 5,570 \\
\hline $\mathrm{TN}$ & $\mathrm{mg} / \mathrm{L}$ & 736 & 2,590 & 640 & 691 \\
\hline $\mathrm{TP}$ & $\mathrm{mg} / \mathrm{L}$ & 258 & 703 & 780 & 780 \\
\hline
\end{tabular}

\section{B. Experimental Procedures}

The schedule of microcosm experiments consisted of two flow stages; the first is the circulation stage and the second is the treatment stage (Fig. 1). For the circulation stage, a raw wastewater from a sewage treatment plant and synthetic wastewater was initially mixed $(1 \mathrm{~L}$ of raw wastewater and $35 \mathrm{~L}$ of synthetic wastewater) and recycled through the microcosm system to accelerate biofouling of the bundle of coconut fibre. During the circulation stage, water samples in 
the supply tank and treatment tanks were collected on a weekly basis to analyze the basic water quality parameters such as chemical oxygen demand $\left(\mathrm{COD}_{\mathrm{cr}}\right.$; hereafter just COD), biological oxygen demand (BOD), total carbon (TC), total phosphorus (TP), total nitrogen (TN), pH, dissolved oxygen (DO), oxidation reduction potential (ORP), and electrical conductivity (EC). The water and sludge in the supply tank and treatment tank were removed, after completion of the circulation stage. Carbon and nitrogen contents of the coir fibre and sludge settled at the bottom of the treatment tank were quantified. For the subsequent treatment stage, the microcosm system was first filled with the synthetic wastewater solution. Secondly, the synthetic sewage/synthetic leachate solution was supplied continuously from the supply tank. The water quality parameters were measured once a week during the treatment stage.

\section{RESUlTS AND DisCUSSION}

\section{A. Removal \% Changes in Water Quality Parameters under Circulation and Treatment Stages}

The removal $\%$ in the circulation stage and treatment stage of each parameter was calculated using the following equation.

$$
\text { Removal \%= } \frac{\text { Inflow }(\mathrm{mg} / \mathrm{L})-\text { Outflow }(\mathrm{mg} / \mathrm{L})}{\text { Inflow }(\mathrm{mg} / \mathrm{L})} \times 100
$$

Fig. 2 and 3 exemplify the variations in removal \% of BOD, COD, TC, TP and TN. Generally, the removal \% of all parameters in the synthetic leachate became higher than those for the synthetic sewage. In particular, the removal \% of BOD and COD from the synthetic leachate in LFD and HFD conditions became higher than those of the blank, indicating that coconut fibre in the treatment tank contributed to the treatment of wastewater. The removal \% of BOD and COD in low load conditions became higher than those in high load conditions, implying that the proper control of pollutant loads is useful to improve the treatment of leachate in COTS.

For the synthetic sewage, on the other hand, the values of removal \% in LFD and HFD conditions were relatively low, indicating that the coconut fibre contributed little or nothing to the treatment of wastewater. Opposite to the results of synthetic leachate, the removal \% of pollutants in high load conditions became generally higher than those in low load conditions. This would also imply that the proper control of pollutant loads is effective to improve the treatment of sewage in COTS.

\section{B. Consumptions of $\mathrm{O}_{2}$ in Microcosm Experiments}

A model of mass balance on $\mathrm{O}_{2}$ consumption in the microcosm system in this study was calculated using following equation.

$$
\begin{gathered}
\text { COD removal }(\mathrm{G})=\text { COD accumulated as sludge }(\mathrm{M}) \\
+ \text { COD accumulated as coconuts fibre }(\mathrm{S}) \\
+ \text { COD removal with Oxygen }(\mathrm{T})
\end{gathered}
$$

An example of calculation sheet for $\mathrm{O}_{2}$ consumption at treatment stage in high concentration of synthetic leachate is shown in Table II. The results of $\mathrm{O}_{2}$ consumption for all tested conditions are summarized in Table III. For the synthetic sewage, the $\mathrm{O}_{2}$ consumption in the microcosm did not vary among Blank, LFD, and HFD. For the synthetic leachate, on the other hand, the $\mathrm{O}_{2}$ consumption in the microcosm for LFD and HFD became higher than that for Blank. For both synthetic sewage and leachate, the $\mathrm{O}_{2}$ consumption in the sludge for LFD and HFD became higher than that for Blank. For the synthetic sewage, some of COD removal with Oxygen became positive (+) due to $\mathrm{CO}_{2}$ emission, while the others became negative (-) due to

\begin{tabular}{|c|c|c|c|c|c|}
\hline \multicolumn{3}{|c|}{$\mathrm{O}_{2}$ Mass Balance in Treatment } & \multirow{2}{*}{$\begin{array}{l}\text { HFD } \\
21,400\end{array}$} & \multirow{2}{*}{$\begin{array}{ll}\text { LFD } \\
21,400\end{array}$} & \multirow{2}{*}{$\begin{array}{r}\text { BLANK } \\
21,400\end{array}$} \\
\hline 1 & COD inflow (mg/l) & $\mathrm{A}$ & & & \\
\hline 2 & $\begin{array}{l}\text { COD outflow (after } \\
\text { treatment) }(\mathrm{mg} / \mathrm{l})\end{array}$ & B & 9,060 & 10,000 & 17,661 \\
\hline 3 & $\begin{array}{l}\text { Initial COD in solution- } \\
\text { final COD in solution }(\mathrm{mg} / \mathrm{l})\end{array}$ & $\mathrm{C}=\mathrm{A}-\mathrm{B}$ & 12,340 & 11,400 & 3,739 \\
\hline 4 & $\begin{array}{l}\text { Volume of leachate in } \\
\text { circulation period ( } \mathrm{L})\end{array}$ & $\mathrm{D}$ & 12 & 12 & 12 \\
\hline 5 & COD inflow $\left(\mathrm{gO}_{2}\right)$ & $\mathrm{E}=\mathrm{AxD} / 1,000$ & 256.8 & 256.8 & 256.8 \\
\hline 6 & $\begin{array}{l}\text { COD outflow (after } \\
\text { treatment) }\left(\mathrm{gO}_{2}\right)\end{array}$ & $\mathrm{F}=\mathrm{BxD} / 1,000$ & 108.7 & 120.0 & 211.9 \\
\hline 7 & COD removal $\left(\mathrm{gO}_{2}\right)$ & $\mathrm{G}=\mathrm{E}-\mathrm{F}$ & 148.1 & 136.8 & 44.9 \\
\hline 8 & $\begin{array}{l}\text { Accumulated Sludge } \\
\text { mass }(\mathrm{g})\end{array}$ & $\mathrm{H}$ & 73 & 55 & 33 \\
\hline 9 & $\mathrm{C}$ content in sludge $(\%)$ & I & 20.01 & 21.63 & 20.93 \\
\hline 10 & $\begin{array}{l}\text { C content in accumulated } \\
\text { of sludge }(\mathrm{g})\end{array}$ & $\mathrm{J}=(\mathrm{HxI}) / 100$ & 14.6 & 11.9 & 6.9 \\
\hline 11 & $\begin{array}{l}\text { Conversion of C content } \\
\text { in Sludge to VSS }(\%)\end{array}$ & $\begin{array}{c}\mathrm{K}=(\mathrm{G}+0.043) \\
/ 0.52\end{array}$ & 38.6 & 41.7 & 40.3 \\
\hline 12 & $\begin{array}{l}\text { VSS content in } \\
\text { accumulated sludge }(\mathrm{g})\end{array}$ & $\mathrm{L}=(\mathrm{FxK}) / 100$ & 28.2 & 22.9 & 13.3 \\
\hline 13 & $\begin{array}{l}\text { Conversion of VSS to } \mathrm{O}_{2} \\
\text { consumed }\left(\mathrm{gO}_{2}\right)\end{array}$ & $\mathrm{M}=\mathrm{Lx} 1.42$ & 40 & 32.5 & 18.9 \\
\hline 14 & Dry mass of coir fibre $(\mathrm{g})$ & $\mathrm{N}$ & 36.03 & 17.97 & - \\
\hline 15 & $\begin{array}{l}\text { C content in coir fibre } \\
\cong \text { after circulation }(\%)\end{array}$ & $\mathrm{O}$ & 41.13 & 44.5 & - \\
\hline 16 & $\begin{array}{l}\text { C content in raw coir fibre } \\
\Xi(\%)\end{array}$ & $\mathrm{P}$ & 40.8 & 40.8 & - \\
\hline 17 & $\begin{array}{l}\tilde{J} \text { Accumulated } \mathrm{C} \text { mass in in } \\
\text { coir fibre }(\mathrm{g})\end{array}$ & $\begin{array}{c}\mathrm{Q}=(\mathrm{O}-\mathrm{P}) \mathrm{xN} \\
/ 100\end{array}$ & 0.1 & 0.7 & - \\
\hline 18 & $\begin{array}{l}\text { Conversion of } \\
\text { accumulated } \mathrm{C} \text { to VSS (g) }\end{array}$ & $\begin{array}{c}\mathrm{R}=(\mathrm{Q}+0.043) \\
/ 0.52\end{array}$ & 0.3 & 1.4 & \\
\hline 19 & $\begin{array}{l}\text { Conversion of VSS to } \mathrm{O}_{2} \\
\text { consumed }\left(\mathrm{gO}_{2}\right)\end{array}$ & $\mathrm{S}=\mathrm{R} \times 1.42$ & 0.4 & 2.0 & \\
\hline 20 & $\begin{array}{l}\text { COD removal with } \\
\text { Oxygen (e.g., } \mathrm{CO}_{2} \\
\text { emissions) }\left(\mathrm{gO}_{2}\right)\end{array}$ & $\mathrm{T}=\mathrm{G}-\mathrm{M}-\mathrm{S}$ & 107.7 & 102.3 & $\overline{26.0}$ \\
\hline
\end{tabular}
biomass growth via photosynthesis.

TABLE II: AN EXAMPLE OF CALCULATION SHEET FOR $\mathrm{O}_{2}$ CONSUMPTION AT TREATMENT STAGE IN HiGH CONCENTRATION OF SYNTHETIC LEACHATE

\section{Some Factors Considered between Filed COTS and} Laboratory Microcosm Experiments

There are several factors considered resulting in the performance of wastewater treatment between filed COTS and laboratory microcosm experiments. One of the significant factors can be the difference in light intensity and wavelength, and temperature. In this microcosm experiments, we have adopted a lightning system with the illumination intensity of 4,730 lux and with its wavelength close to the sunlight and the constant temperature condition of $20{ }^{\circ} \mathrm{C}$. However, there was very few growth of algae observed in the laboratory while a rich growth of algae has been observed in the field. These differences affect the $\mathrm{O}_{2}$ consumption on the coconut-fibre surface and sludge sedimentation, resulting in the performance of wastewater treatment between filed 
COTS and laboratory microcosm experiments (see TABLE III). Besides, other factors such as the difference in suspended solids (SS) and salts in the wastewater might affect the performance of COTS. The synthetic leachate and sewage without any SS were used in the laboratory microcosm experiments. On the other hand, in the field COTS, there observed some amount of SS in the treatment tank. This difference also affected the treatment efficiency especially on the removal of $\mathrm{C}, \mathrm{N}, \mathrm{P}$ by the sludge sedimentation.

\begin{tabular}{|c|c|c|c|c|c|c|c|c|c|c|c|c|c|}
\hline \multicolumn{7}{|c|}{ Synthetic sewage } & \multicolumn{7}{|c|}{ Synthetic leachate } \\
\hline \multirow{2}{*}{ 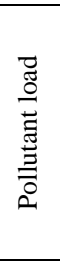 } & \multirow{2}{*}{$\begin{array}{l}\stackrel{\infty}{\infty} \\
\stackrel{\Xi}{\infty}\end{array}$} & \multirow{2}{*}{ 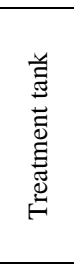 } & $\begin{array}{c}\mathrm{O}_{2} \\
\text { consumed in } \\
\text { the } \\
\text { microcosm }\end{array}$ & $\begin{array}{l}\stackrel{\mathrm{O}_{2}}{\text { consumed }} \\
\text { in sludge }\end{array}$ & $\begin{array}{c}\mathrm{O}_{2} \\
\text { consumed } \\
\text { in coir } \\
\text { fibre }\end{array}$ & $\begin{array}{c}\text { COD } \\
\text { removal with } \\
\text { Oxygen } \\
\text { (e.g.,. } \mathrm{CO}_{2} \\
\text { emissions) }\end{array}$ & \multirow{2}{*}{ 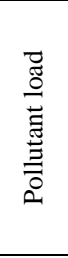 } & \multirow{2}{*}{$\begin{array}{l}\mathscr{D}_{0} \\
\stackrel{\Xi}{\mathscr{S}}\end{array}$} & \multirow{2}{*}{ 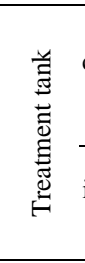 } & $\begin{array}{c}\mathrm{O}_{2} \\
\text { consumed in } \\
\text { the } \\
\text { microcosm }\end{array}$ & $\begin{array}{l}\mathrm{O}_{2} \\
\text { consumed } \\
\text { in sludge }\end{array}$ & $\begin{array}{c}\mathrm{O}_{2} \\
\text { consumed } \\
\text { in coir } \\
\text { fibre }\end{array}$ & $\begin{array}{c}\mathrm{COD} \\
\text { removal with } \\
\text { Oxygen } \\
\text { (e.g., } \mathrm{CO}_{2} \\
\text { emissions) }\end{array}$ \\
\hline & & & $\begin{array}{c}\mathrm{COD} \\
\text { inflow-COD } \\
\text { outflow in } \\
\left.\mathrm{gO}_{2}\right) \\
\end{array}$ & $\left(\mathrm{gO}_{2}\right)$ & $\left(\mathrm{gO}_{2}\right)$ & $\left(\mathrm{gO}_{2}\right)$ & & & & $\begin{array}{c}\text { COD } \\
\text { inflow-COD } \\
\text { outflow in } \\
\left.\mathrm{gO}_{2}\right)\end{array}$ & $\left(\mathrm{gO}_{2}\right)$ & $\left(\mathrm{gO}_{2}\right)$ & $\left(\mathrm{gO}_{2}\right)$ \\
\hline \multirow[t]{6}{*}{ Low } & Circulation & Blank & 5.5 & 2.8 & - & 2.7 & \multirow[t]{6}{*}{ Low } & Circulation & Blank & 12.6 & 4.3 & - & 8.3 \\
\hline & (6weeks) & LFD & 4.3 & 2.8 & 4.0 & -2.5 & & (6weeks) & LFD & 13.1 & 5.8 & 2.0 & 5.3 \\
\hline & & HFD & 4.7 & 3.1 & 5.5 & -3.9 & & & HFD & 14.3 & 6.0 & 2.3 & 6.0 \\
\hline & Treatment & Blank & 1.6 & 1.3 & - & 0.3 & & Treatment & Blank & 10.8 & 4.3 & - & 4.3 \\
\hline & (6weeks) & LFD & 1.8 & 2.7 & 2.6 & -3.5 & & (18weeks) & LFD & 14.4 & 5.8 & 0.1 & 6.8 \\
\hline & & HFD & 0.6 & 3.4 & 3.7 & -6.5 & & & HFD & 14.6 & 6.0 & 1.3 & 4.1 \\
\hline \multirow[t]{6}{*}{ High } & Circulation & Blank & 12.0 & 1.7 & - & 10.3 & \multirow[t]{6}{*}{ High } & Circulation & Blank & 59.0 & 22.2 & - & 36.8 \\
\hline & (6weeks) & LFD & 12.7 & 4.1 & 4.3 & 4.3 & & (6weeks) & LFD & 101.3 & 46.6 & 2.0 & 52.7 \\
\hline & & HFD & 11.8 & 3.3 & 6.7 & 1.8 & & & HFD & 83.0 & 45.7 & 1.0 & 36.3 \\
\hline & Treatment & Blank & 9.6 & 2.0 & - & 7.6 & & Treatment & Blank & 44.9 & 18.9 & - & 26.0 \\
\hline & (16weeks) & LFD & 9.2 & 5.8 & 4.3 & -0.9 & & (22weeks) & LFD & 136.8 & 32.5 & 2.0 & 102.3 \\
\hline & & HFD & 7.8 & 7.5 & 7.2 & -6.9 & & & HFD & 148.1 & 40.0 & 0.4 & 107.7 \\
\hline
\end{tabular}

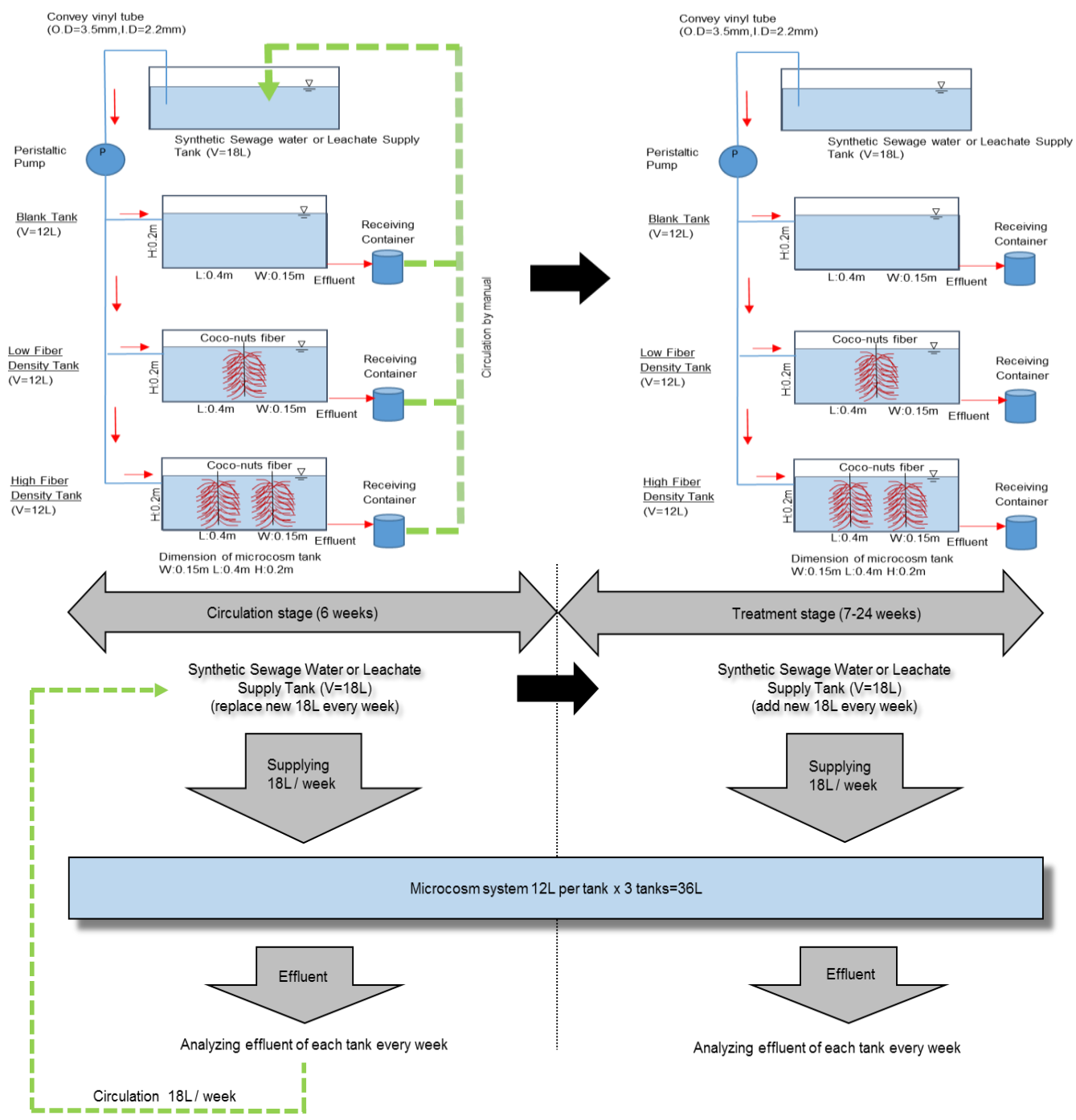

Fig. 1. Schematics of microcosm experiment. 

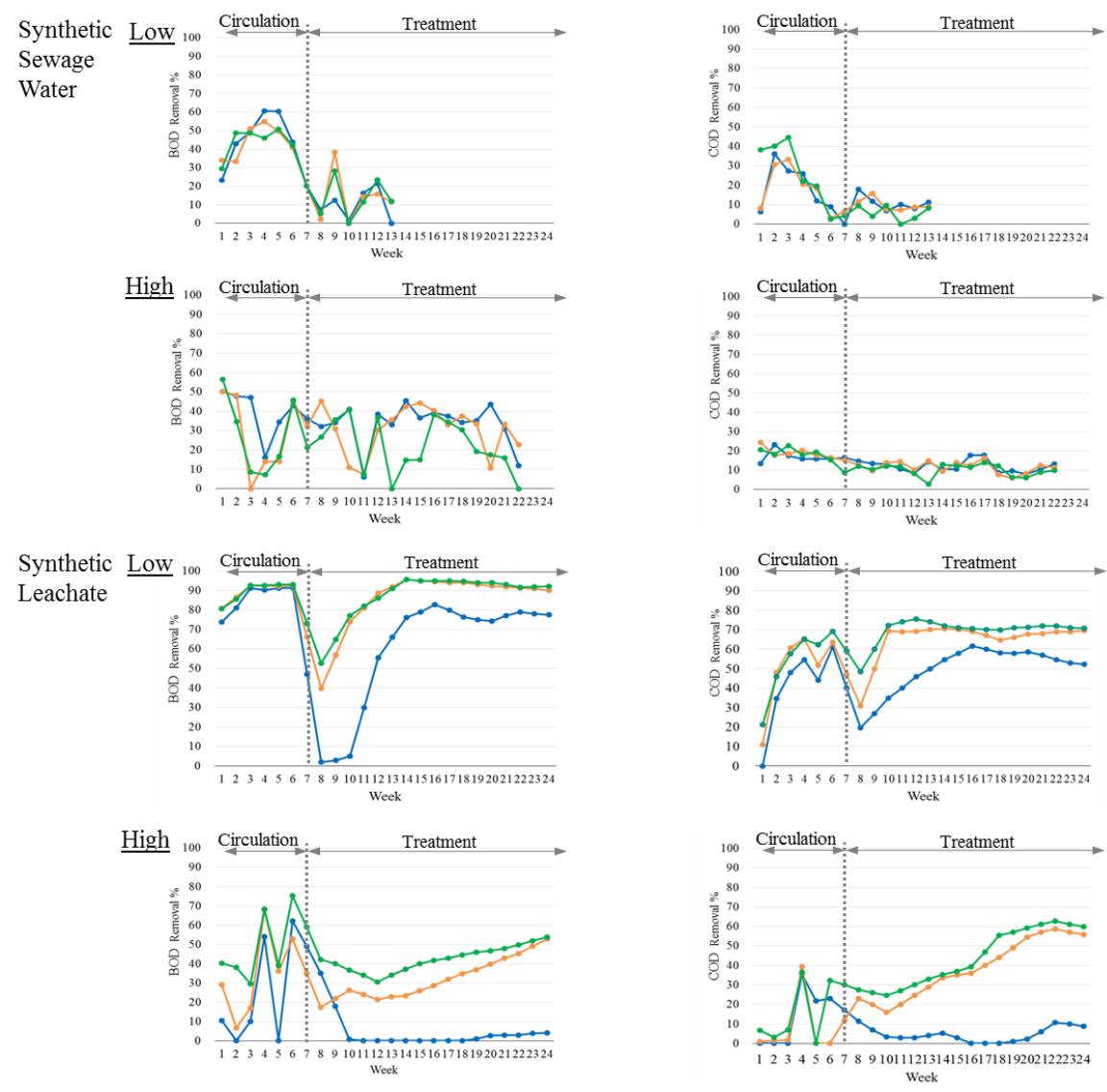

Fig. 2. Variation in removal \% of BOD and COD under circulation and treatment.
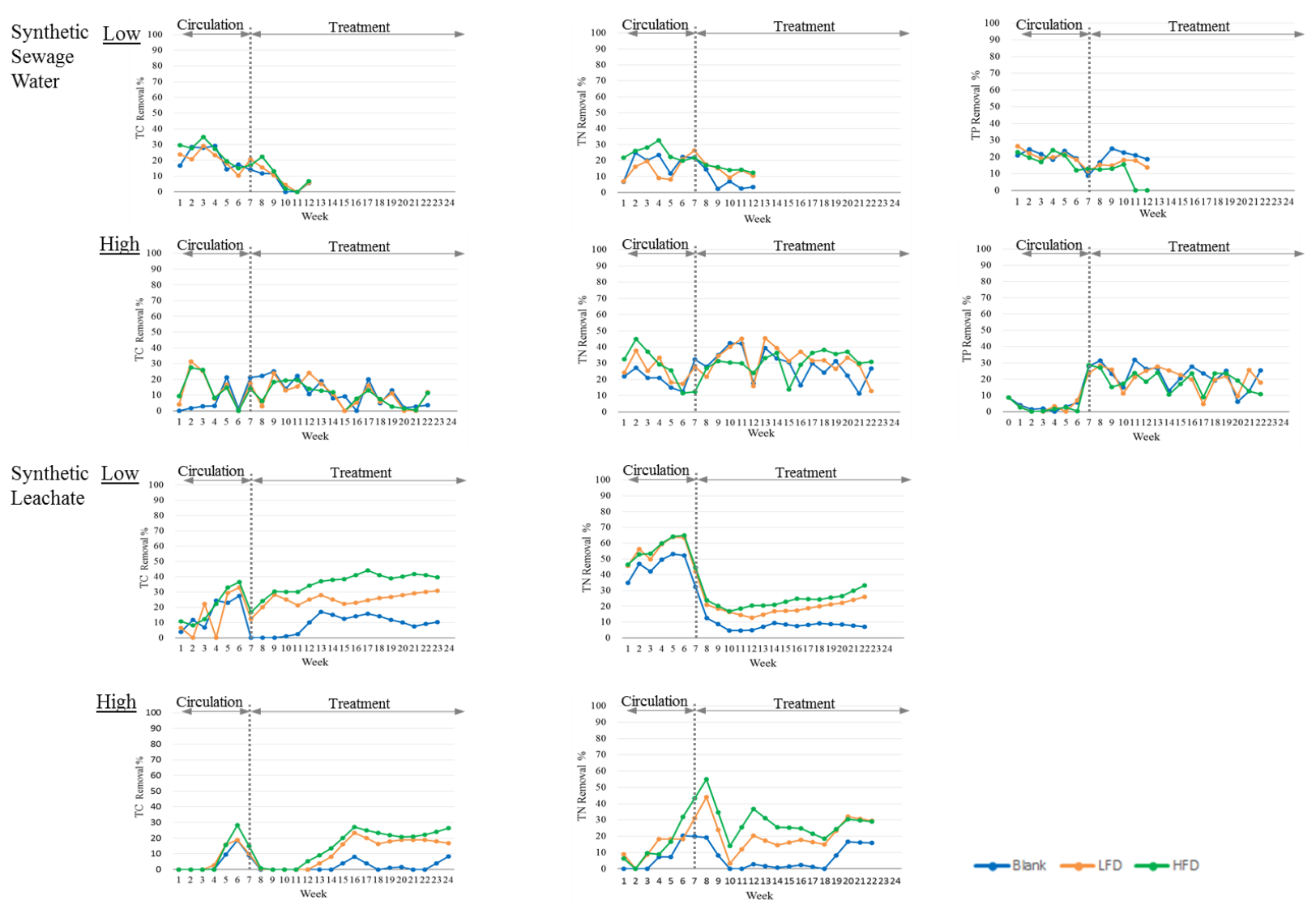

Fig. 3. Variation in removal $\%$ of TC, TN and TP under circulation and treatment.

IV. CONCLUSION

Based on the results of laboratory tests, the microcosm COTS contributes to the reduction of water quality 
parameters such as BOD and COD, especially for the synthetic leachate. The removal $\%$ of pollutants was dependent on the load conditions and the proper control of pollutant loads is effective to improve the treatment efficiencies of sewage and leachate in COTS. The $\mathrm{O}_{2}$ consumption of synthetic leachate was larger than that of synthetic sewage, and the consumption of $\mathrm{O}_{2}$ was larger the larger the coconut fibre density. From these facts, it is considered that the presence or absence of coconut fibre affected $\mathrm{O}_{2}$ consumption of COTS, and high BOD / COD removal efficiency of synthetic leachate under high density coconut fibre condition was obtained.

\section{ACKNOWLEDGMENT}

This study was partially supported by the SATREPS Project of the Japan International cooperation Agency (JICA) and Japan Science and Technology agency (JST).

\section{REFERENCES}

[1] N. Sato et al., "Utilization of a local-available biomass resource for astewater treatment in Sri Lanka: Comparison between initial and current performance of coconut-fibre biofilm treatment system (COTS)," in Proc. 14th Int. Waste Management and Landfill Symposium (Sardinia 2013), p. 181, 2013.

[2] Ministry of Environment \& Natural Resources, Database of Municipal Solid Waste in Sri Lanka, Sri Lanka, 1995.
[3] N. Sato, K. Kawamoto, and L. Mangalika, "Current condition and issues of municipal solid waste management in Sri Lanka," in Proc. 7th Asian-Pacific Landfill Symposium (APLAS 2012), 2012.

[4] N. Sato et al., "Microcosm experiments on a coconut-fibre biofilm treatment system to evaluate wastewater treatment efficiencies," Int. J. GEOMATE, vol. 12, no. 33, pp. 160-166, 2017.

[5] R. Crites and G. Tchobanoglous, Small and Decentralized Wastewater Management Systems, New York: McGraw-Hill Science/Engineering/Math, p. 944, 1998.

[6] B. G. N. Sewwandi et al., "Characterization of landfill leachate from municipal solid waste landfills in Sri Lanka," in Proc. the 2nd International Conference on Sustainable Built Environment (ICSBE 2012), Special Session on Water and Waste Management, 2012.

[7] N. K. Dharmarathne et al., "Evaluation of wastewater treatment efficiency using coconut fibre biofilm reactor system with synthetic leachate," in Proc. International Conference on Engineering and Applied Science (ICEAS), pp. 629-636.

[8] J. F. Gulck and K. Rowe, "Evolution of clog formation with time in columns permeated with synthetic landfill leachate," J. Contam. Hydrol., vol. 75, pp.115-139, 2004

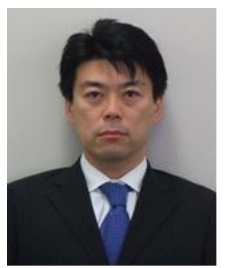

Naofumi Sato belongs to EX Research Institute Ltd. as an environmental consultant. His majors are solid waste management and wastewater engineering. He is Dr. of engineering having graduate from Saitama University at the Graduate School of Science and Engineering. Current his research interest is the treatment of night soil and the leachate from waste disposal site by coconut fibre biofilm. 